\title{
Distribution and Variation of Some Pesticides in Ground and Rural tap Water in Ausiem City, Giza, Egypt
}

\author{
Magdy D. Madbouly*
}

\begin{abstract}
This study was conducted to determine the distribution of some organochlorine (OC) and organophosphorus (OP) pesticides in ground and rural tap water of Ausiem city. For ground water, the monitoring has focused on ground water near agricultural fields (ten locations), and rural tap water (ten locations). Twenty water samples were analyzed for a total of seventeen pesticide compounds, aldrin, dieldrin, $\alpha, \beta$ and $\gamma$-hexachlorocyclohexane $(\mathrm{HCH})$, dichlorodiphenyltrichloroethane (DDTs) heptachlor, heptachlor epoxide as OC and malathion, parathion, dimethoate and tolclofos-methyl as OP pesticides. The DDT and its related compounds (DDD, DDE) were detected in most water samples. For ground and tap water O,P DDT showed a high concentration among DDT's and organochlorine pesticides with concentration of $5.36 \mu \mathrm{g} / \mathrm{L}$ at site 7 . The obtained data showed that the total OP residues were lower than $\mathrm{OC}$ pesticides in both types of investigated waters. In most cases, the total OC and OP residues were extremely higher than most polluted water from other sources in the world. Some of pesticide residues were generally low, and some were not detectable although high concentrations also occurred, for example, total of 14.84 and $12.86 \mu \mathrm{g} / \mathrm{L}$ (as OC and OP) of ground water and rural tap water, respectively. The results show that both local ground water near farms and rural tap water is vulnerable for contamination of $\mathrm{OC}$ and $\mathrm{OP}$ pesticides and need further monitoring.
\end{abstract}

Keyword: Water pollution . Organochlorine pesticides, Organophosphorus pesticides ,Gas chromatography, Ausiem City.

\section{1- Introduction}

Environmental contamination of natural waters by pesticides residues is of a great concern. Pesticides are one class of compounds that, despite their benefits, may produce a wide range of toxic side effects that pose potential hazards to the environments. Pesticides are the major source of concern as water pollutants. Because of their stability and persistence, the most hazardous pesticides are Organochlorine pesticides. Organochlorine pesticides (OC) are considered to be dangerous not only for the environment but for human beings as well. OC represent an important group of persistent organic pollutants

\footnotetext{
*Assistant Professor, Department of Environmental Research, Chemical and Biological Rescarch Divison. The National Center for Social and Criminological Research.
}

The National Review of Criminal Sciences, Volume 64, No.1, March 2021. 
(POPs) which are believed to be possible carcinogens as well as endocrine disruptors ${ }^{(1)}$. Although the use of all organochlorine pesticides (OCPs) have been prohibited in Egypt in the 1980s by the Ministry of Agriculture, some previous investigations showed that pesticides in some surface water in Egypt have been detected with different levels. Great efforts have been made to study pesticide pollution in water, sediment, aquatic weeds, and fish status in Manzala Lake and River Nile water, lake of Qarun, Alexandria, Damietta, AlHarm, Giza during the last years ${ }^{(2-11)}$. In an effort to substitute these persistent organochlorine pesticides, agricultural sectors have shifted towards organophosphate pesticides ${ }^{(12)}$. However, organophosphate pesticides are generally much more toxic to vertebrates compared to other classes of insecticides even though they rapidly degrade in the environment ${ }^{(13)}$. The usage of these pesticides has brought about great concern in the scientific community on the possible toxic effects of these pesticide contaminations to both aquatic flora and fauna as well as to humans ${ }^{(14)}$. Usage of organophosphorus pesticides on agricultural and urban areas has resulted in pollution of natural water resources such as surface water and ground water ${ }^{(15)}$. Organophosphorus chemicals do not easily volatilize from soil or water and are associated with toxicity of aquatic organisms. Organophosphorus pesticides are inhibitor of acetylcholinesterase enzyme and are also responsible for poisoning of humans ${ }^{(16)}$. The pesticides enter the water system through human activities, such as agriculture and industry. Therefore, great attention is given by United States Environmental Protection Agency (USEPA) and United States Food and Drug Administration (USFDA) to control their levels in the environment ${ }^{(17-19)}$. Primary pollutions may spread through runoffs from usage areas to lakes, rivers and also aquifers. Polluted surface water and ground water are eventually used as direct source or resources of raw water for community drinking water systems ${ }^{(20)}$. Water resource is very important in natural environment and essential to agriculture. There are many reports about contamination of surface water by pesticides ${ }^{(21)}$. The use of pesticides would affect the water quality and their residues were threats to the human health.

The aim of this study was to investigate pesticide pollution of water supplies in agricultural areas of Ausiem, Giza, Egypt. The 
objectives were to identify ground sources and rural tap water in Ausiem city at high risk of agrochemical contamination, to identify and quantify the presence of agrochemicals at these selected sites and to explore the implications for human health. For assessment of the possible chronic health and environmental effects of long-term exposure to pesticides, extended monitoring of ground and drinking water, as well as analytical techniques with sufficiently low levels of detection are essential. As monitoring of pesticide water pollution is a substantial source of information describing the current state of environmental pollution and reflecting the effectiveness of environmental legislation policies.

Our study was conducted to obtain large scale monitoring data on spatial distribution of selected organochlorine and organophosphorus pesticides in water samples collected at different 20 sampling sites (10 for ground and 10 for rural tap water) along the Ausiem city.

\section{2- Description of the studied area}

Ausiem city is one of the oldest places which affiliated to the governorate of Giza, was known as Lycopolis in the era of the pharaohs of Egypt and was part of the countryside of Memphis. It is located near the capital Cairo and about 20 kilometers away from E1Qanater El-Khayreya in Al Qalyubia governorate and then the way is open in front of you to the different provinces of the Delta. As for the human nature of the population of current Ausiem, we can see that it descended from rural backgrounds through the past ages. It has been mainly dependent on agriculture, acquiring its resources from what God blessed this land of fertile soil and abundant water. Concerning the weather in Ausiem, we will always feel noticeable lower temperatures compared to Cairo, despite the proximity. This is due to the expansion of the agricultural area surrounding it and its great height above sea level. Ausiem is considered as one of the crowded area, and like all rural areas of the Arab Republic of Egypt, most of the population of the city Ausiem and not so long they rely on drinking water that is extracted from the ground by conventional pumping and some on water treatment plants. Pumps are manufactured locally. Water is extracted through a pipe (tube) made of iron at a depth of several meters $(15-20 \mathrm{~m})$ in the ground until it 
reaches the groundwater level. Since the residential area is surrounded by large tracts of agricultural and most farmers use large amounts of organic pesticides, the likelihood of leakage of large quantities of these pesticides into the groundwater, which is used as drinking water is possible.

Table (1): Analyzed pesticides, limits of detection and limits of quantification data in the GC-ECD $\left(\mu \mathrm{g} / \mathrm{L}^{-1}\right)$

\begin{tabular}{|c|c|c|}
\hline Pesticides & LOD & LOQ \\
\hline Aldrin & 0.003 & 0.009 \\
\hline$\alpha$-HCH & 0.004 & 0.012 \\
\hline$\beta$-HCH & 0.004 & 0.012 \\
\hline$\gamma$-HCH & 0.004 & 0.012 \\
\hline Dieldrin & 0.003 & 0.009 \\
\hline O,P-DDE & 0.002 & 0.006 \\
\hline P,P-DDE & 0.002 & 0.006 \\
\hline O,P-DDD & 0.004 & 0.012 \\
\hline P,P-DDD & 0.004 & 0.012 \\
\hline O,P-DDT & 0.003 & 0.009 \\
\hline P,P-DDT & 0.003 & 0.009 \\
\hline Heptachlor & 0.004 & 0.012 \\
\hline H. Epoxide & 0.004 & 0.012 \\
\hline Dimethoate & 0.003 & 0.009 \\
\hline Malathion & 0.004 & 0.012 \\
\hline Tolc. methyl & 0.002 & 0.002 \\
\hline Parathion & 0.003 & 0.009 \\
\hline
\end{tabular}

\section{Experimental section}

\subsection{Chemicals}

Pure analytical insecticide standards used were purchased in part from Ultra Scientific, 250 Smith Street, North Kingdom, R102852 and in part from Allteck (Sedriano, Italy). Individual standard solutions were prepared by dissolving $20 \mathrm{mg}$ of the pesticides in $20 \mathrm{~mL}$ of $\mathrm{n}$-hexane. All solvents were used were HPLC grade and purchased from BDH.

\subsection{Sampling}

A total of 20 water samples were collected from random sites and kept in sterilized brown bottles at $4^{\circ} \mathrm{C}$ in the dark until analysis. The pesticide standards were quantified individually and as a mixture by using gas chromatography with electron capture detector GC/ECD. The sample residues were quantified either by using GC/ECD for routine quantization or on the basis of selected ions by using GC/MS with electron impact (EI) for confirmatory quantization ${ }^{(22)}$. 


\subsection{Extraction of water samples}

Liquid- liquid extraction, followed by gas chromatographic analysis, was used for the determination of pesticide residues ${ }^{(22)}$. Around 1 liter of the water sample was filtered using a $0.45 \mu \mathrm{m}$ Whatman glass fiber paper filter treated with $10 \mathrm{~g}$ of sodium sulfate and extracted twice with $75 \mathrm{ml}$ of methylene oxide. The combined extracts were filtered and concentrated in a vacuum rotatory evaporator. The solution obtained was filtered with sodium sulfate and completed with hexane, up to $5 \mathrm{ml}$ and $1 \mu \mathrm{L}$ of this solution was injected and analyzed.

\subsection{GC/ECD determination}

The residues were chromatographed on HP 5890 A $63 \mathrm{Ni}$ ECD gas chromatography using a $6 \mathrm{ft} \times 4 \mathrm{~mm}$ id, 6 inch coil of 0.125 inch OD stainless steel column packed with $10 \% \mathrm{OV}-17,80-100$ mesh on chromosorb WHP. The oven temperature schedule of OV-17 column as follows: initial temperature was $150^{\circ} \mathrm{C}$ for $1 \mathrm{~min}$., ramp $1,10^{\circ} \mathrm{C}$ for $2 \mathrm{~min}$., ramp 2, then the temperature hold at $300^{\circ} \mathrm{C}$ for $5 \mathrm{~min}$., ramp 3 . The nitrogen carrier gas was $63 \mathrm{ml} / \mathrm{min}$., the injector temperature was $280^{\circ} \mathrm{C}$, and the detector temperature was $325^{\circ} \mathrm{C}$. The GC/MS was a Varian 3400 GC coupled with a Finigan SQ 700 mass selective detector employing EI at $70 \mathrm{eV}$. The determination of the residues was based on the peak area of the sample to that of the corresponding external standards given on a HP 3392. Computing integrator coupled to the gas chromatograph ${ }^{(22)}$.

\subsection{Quality assurance and recovery}

The quality of organochlorine and organophosphorus pesticides was assured through the analysis of solvent blanks, procedure blanks and duplicate samples. All reagents used during the analysis were exposed to same extraction procedures and subsequently run to check for interfering substances. In the blank for each extraction procedure no pesticide was detected. Sample of each series was analyzed in triplicates. The method was optimized and validated by spiking the water samples with $100 \mu \mathrm{L}$ of $100 \eta \mathrm{L}^{-1}$ standard mixture before analysis to evaluate the recovery of compounds. The mean recoveries of internal standards ranged between $79 \%$ and $91 \%$ and between $86 \%$ and $94 \%$ for all organochlorine and organophosphorus pesticides analyzed, respectively. The limits of detection (LOD) were varied 
from $0.002-0.04 \mu \mathrm{g} / \mathrm{L}^{-1}$ for all pesticides. The limits of detection (LOD) of studied pesticides were determined as the concentration of analyses in a sample that gives rise to a peak with a signal-to-noise ratio $(\mathrm{S} / \mathrm{N})$ of $1: 3$. The limits of detection (LOD) and the limits of quantification (LOQ) data in the GC-ECD was presented in Table (1). Sample of each series was analyzed in triplicates.

\section{Results and Discussion}

The quantities of pesticides used in Egypt based on Environmental Affairs agency, Egypt; January 2009, is about 600 ton/annually. Therefore, the spatial distribution of eight organochlorine with their isomers and four organophosphorus pesticide residues in the main water source for Ausiem city was investigated. It is well known that most of the applied pesticides are subject to many transport and conversion products. Thus, they do not remain at their target site but often enter aquatic environment via soil percolation, air drift or surface runoff affecting abundance and diversity of non-target species producing complex effects on the ecosystems and altering tropic interactions ${ }^{(23)}$. In addition, many pesticides eventually end up in ground water and their transformation products may remain for years ${ }^{(24)}$. The results of the analysis of the water samples from Ausiem have shown the presence of both organochlorine and organophosphate pesticides. The compounds detected were hexachlorocyclohexane (the isomers $\alpha-, \beta-$, and $\gamma-, \mathrm{HCH}$ ), DDT (the isomers DDE and DDD), aldrin, dieldrin, heptachlor and heptachlor epoxide as organochlorine pesticides and dimethoate, malathion, tolclofos-methyl and parathion, as organophosphorus pesticides. Results of the samples analysis are summarized in Tables $(2,3)$.

\subsection{Existence of organochlorine pesticides}

DDT is one of the most controversial chemical compounds in recent history. It has proven effective as an insecticide, but its potent toxicity isn't limited to insects. DDT is banned by many countries including the United States and Egypt. It is nonetheless still used -legally or illegallyin some places. As a result of its tendency to dissolve in fats, DDT can build up in the fatty tissues of animals that are exposed to it. This accumulated build-up is known as bioaccumulation, and DDT is described by the USEPA as a persistent, bio-accumulative toxin. 
Because of this bioaccumulation, DDT remains in the food chain, DDT also has serious health effects on humans. According to the USEPA, DDT can cause liver damage including liver cancer, nervous system damage, congenital disabilities, and other reproductive harm.

Table (2) compiles the data of investigated ground water, the data revealed that site 2 was the most contaminated by OC pesticides where the total concentrations were $12.4 \mu \mathrm{g} / \mathrm{L}$ followed by site 5 where it recorded $10.5 \mu \mathrm{g} / \mathrm{L}$. The site number 6 was the least contaminated where it recorded total concentration of $0.79 \mu \mathrm{g} / \mathrm{L}$. It was cleared that DDT and its isomers were the predominant pesticides in all investigated sites. O,P-DDT recorded $4.52 \mu \mathrm{g} / \mathrm{L}$ and $5.36 \mu \mathrm{g} / \mathrm{L}$ at sites number 5 and 7 , respectively. The high concentrations for $\mathrm{P}, \mathrm{P}$ DDT revealed $4.15 \mu \mathrm{g} / \mathrm{L}$ and $3.70 \mu \mathrm{g} / \mathrm{L}$ at sites 2 and 9 , respectively. In comparison with these isomers' concentrations, $\mathrm{O}$ and $\mathrm{P}$ DDE and O,P DDD showed lower concentrations in the investigated sites.

For studied rural tap water samples, Table (3), the data revealed that site 7 was the most contaminated by OC pesticides where the total concentrations were $10.3 \mu \mathrm{g} / \mathrm{L}$ followed by site 10 where it recorded $9.12 \mu \mathrm{g} / \mathrm{L}$. The data showed also that the least contaminated site was site 2 where it recorded $2.67 \mu \mathrm{g} / \mathrm{L}$.

Table (2): Mean concentrations of organochlorine and organophosphorus pesticides $(\mu \mathrm{g} / \mathrm{L})$ detected in ground water samples at Ausiem City, Egypt

\begin{tabular}{|c|c|c|c|c|c|c|c|c|c|c|}
\hline Pesticides & \multicolumn{10}{|c|}{ Sites } \\
\hline & 1 & 2 & 3 & 4 & 5 & 6 & 7 & 8 & 9 & 10 \\
\hline & \multicolumn{10}{|c|}{ Organochlorine } \\
\hline Aldrin & 0.28 & n.d & n.d & n.d & n.d & n.d & n.d & 0.36 & n.d & n.d \\
\hline$\alpha-\mathrm{HCH}$ & 0.35 & n.d & n.d & n.d & n.d & n.d & n.d & 0.36 & n.d & n.d \\
\hline$\beta-\mathrm{HCH}$ & n.d & 0.56 & 1.25 & 0.28 & 0.51 & n.d & 0.56 & 1.25 & 0.27 & 0.51 \\
\hline$\gamma-\mathrm{HCH}$ & 0.30 & n.d & 0.15 & 0.28 & 0.37 & 0.16 & 0.35 & 0.15 & 0.32 & 0.26 \\
\hline Dieldrin & 0.37 & 0.56 & 0.11 & 0.22 & 0.11 & 0.22 & 0.25 & n.d & 0.37 & 0.24 \\
\hline O,P-DDE & 0.40 & n.d & 0.53 & n.d & 0.50 & n.d & 0.48 & 0.86 & n.d & 0.34 \\
\hline P,P-DDE & 0.39 & 0.47 & n.d & n.d & n.d & n.d & 0.41 & n.d & n.d & n.d \\
\hline O,P-DDD & 0.23 & 0.29 & n.d & n.d & n.d & n.d & 0.26 & n.d & 0.21 & n.d \\
\hline P,P-DDD & 1.21 & 0.71 & 0.54 & n.d & n.d & n.d & 1.16 & n.d & n.d & n.d \\
\hline O,P-DDT & n.d & 3.48 & n.d & 2.10 & 4.52 & n.d & 5.36 & 1.57 & 1.11 & 3.15 \\
\hline P,P-DDT & 2.02 & 4.15 & 0.40 & 0.32 & 3.81 & 0.16 & 1.23 & 1.58 & 3.70 & 0.11 \\
\hline Heptachlor & n.d & 1.75 & n.d & n.d & n.d & n.d & n.d & 0.32 & 0.10 & n.d \\
\hline H. Epoxide & 0.10 & 0.40 & 0.10 & 0.34 & 0.64 & 0.25 & 0.21 & 0.1 & 0.37 & 0.65 \\
\hline Total OC & 5.65 & 12.4 & 3.08 & 3.54 & 10.5 & 0.79 & 10.3 & 6.55 & 6.45 & 5.26 \\
\hline \multicolumn{11}{|c|}{ Organophosphorus } \\
\hline Dimethoate & n.d & 0.34 & n.d & n.d & n.d & n.d & n.d & 0.86 & 1.07 & 1.39 \\
\hline Malathion & 0.52 & n.d & n.d & n.d & n.d & n.d & 1.66 & n.d & 2.41 & n.d \\
\hline Tolc. methyl & 3.63 & n.d & 0.82 & 0.30 & n.d & n.d & n.d & n.d & n.d & n.d \\
\hline Parathion & 0.20 & 2.1 & 0.1 & n.d & n.d & n.d & 0.44 & n.d & 0.31 & n.d \\
\hline Total OP & 4.35 & 2.44 & 0.92 & 0.30 & n.d & n.d & 2.1 & 0.86 & 3.79 & 1.39 \\
\hline
\end{tabular}


The concentrations of DDT related compounds were higher at site 10 where it recorded $8.38 \mu \mathrm{g} / \mathrm{L}$ and lower at site 6 where it recorded 1.55 $\mu \mathrm{g} / \mathrm{L}$. As expected, the diversity and presence of these pesticides is due to the adoption of a water treatment plant that feeds the Ausiem region on contaminated River Nile water ${ }^{(25)}$. In a study of surface waters in the USA during 1964-1968, the highest level recorded for a DDT-related compound was $0.84 \mu \mathrm{g} / \mathrm{L}$. Concentrations in Germany were even lower, averaging $10 \mathrm{ng} / \mathrm{L}$ and never going as high as 1 $\mu \mathrm{g} / \mathrm{L}$. The average

concentrations of total DDT in drinking-water in Czechoslovakia were 11 and $15 \mathrm{ng} / \mathrm{L}$ in 1972 and 1973, respectively. DDT was not detected (limit $0.01 \mathrm{ng} / \mathrm{L}$ ) in tap water in a 1977 survey carried out in Ottawa, Canada $^{(26)}$.

Table (3): Mean concentrations of organochlorine and organophosphorus pesticides $(\mu \mathrm{g} / \mathrm{L})$ detected in rural tap water samples at Ausiem City, Egypt.

\begin{tabular}{|c|c|c|c|c|c|c|c|c|c|c|}
\hline \multirow[t]{2}{*}{ Pesticides } & \multicolumn{10}{|c|}{ Sites } \\
\hline & 1 & 2 & 3 & 4 & 5 & 6 & 7 & 8 & 9 & 10 \\
\hline \multicolumn{11}{|c|}{ Organochlorine (OC) } \\
\hline Aldrin & n.d & 0.77 & n.d & n.d & n.d & n.d & n.d & n.d & n.d & n.d \\
\hline$\alpha-\mathrm{HCH}$ & 0.77 & 0.19 & n.d & n.d & n.d & n.d & n.d & n.d & n.d & n.d \\
\hline$\beta-\mathrm{HCH}$ & n.d & n.d & n.d & n.d & n.d & n.d & n.d & n.d & n.d & n.d \\
\hline$\gamma-\mathrm{HCH}$ & n.d & n.d & 0.56 & n.d & n.d & n.d & 0.07 & n.d & n.d & n.d \\
\hline Dieldrin & 0.37 & 0.56 & 0.11 & 0.22 & 0.11 & 0.22 & 0.25 & n.d & 0.37 & 0.24 \\
\hline O,P-DDE & n.d & n.d & n.d & 0.79 & n.d & n.d & 0.72 & n.d & 0.43 & 1.48 \\
\hline P,P-DDE & 0.32 & 0.22 & n.d & 0.27 & n.d & n.d & 0.14 & 0.13 & n.d & 0.26 \\
\hline O,P-DDD & n.d & 0.03 & n.d & n.d & n.d & n.d & n.d & 0.29 & n.d & 0.04 \\
\hline P,P-DDD & n.d & 0.03 & n.d & n.d & n.d & n.d & n.d & 0.29 & n.d & 0.05 \\
\hline O,P-DDT & n.d & n.d & n.d & n.d & 0.20 & n.d & 5.36 & 1.57 & 1.11 & 3.15 \\
\hline P,P-DDT & 1.30 & 1.55 & 2.00 & 0.55 & 3.60 & 1.55 & 1.31 & n.d & 2.09 & 1.40 \\
\hline Heptachlor & 1.60 & 0.74 & n.d & 3.19 & 2.62 & 2.40 & 2.43 & 2.18 & 2.50 & 2.50 \\
\hline H. Epoxide & n.d & n.d & n.d & n.d & n.d & 0.56 & n.d & n.d & 0.87 & n.d \\
\hline Total OC & 4.30 & 4.09 & 2.67 & 5.02 & 6.53 & 4.73 & 10.3 & 4.46 & 7.37 & 9.12 \\
\hline \multicolumn{11}{|c|}{ Organophosphorus (OP) } \\
\hline Dimethoate & n.d & 0.86 & n.d & n.d & n.d & 0.37 & n.d & n.d & n.d & n.d \\
\hline Malathion & n.d & n.d & n.d & 1.58 & n.d & n.d & n.d & 3.10 & n.d & n.d \\
\hline Tolc. methyl & n.d & n.d & n.d & n.d & n.d & n.d & n.d & n.d & n.d & n.d \\
\hline Parathion & 1.03 & 1.16 & n.d & 1.02 & 2.12 & 1.88 & 2.56 & 2.47 & n.d & 1.14 \\
\hline Total OP & 1.02 & 2.02 & n.d & 2.6 & 2.12 & 2.25 & 2.56 & 5.57 & n.d & 1.14 \\
\hline
\end{tabular}


Within the Global Environment Monitoring System Water Network, DDT and its metabolites were found in some rivers during 19791984. The following average concentrations were measured ${ }^{(25)}$ : India, $560 \mathrm{ng} / \mathrm{L}$; Italy, $3 \mathrm{ng} / \mathrm{L}$; Netherlands, < $2 \mathrm{ng} / \mathrm{L}$; USA, $0.2 \mathrm{ng} / \mathrm{L}$; Canada and France, not detected. Besides, the average concentrations recorded in some places in Egypt indicate limits less than WHO guidelines $^{(10 ; 11)}$. In comparison with our data, the total DDT recorded for ground water at sites from 1 to 10 were $4.25,9.1,1.47,2.42,8.83$, $0.16,8.9,3.94,5.02$ and $3.6 \mu \mathrm{g} / \mathrm{L}$, respectively. Consequently, the studied area indicated higher concentrations than WHO guideline ${ }^{(27)}$. The ratios of $(\mathrm{O}, \mathrm{P}$ and $\mathrm{P}, \mathrm{P}) \mathrm{DDE} /(\mathrm{O}, \mathrm{P}$ and $\mathrm{P}, \mathrm{P})$ DDTs and $(\mathrm{O}, \mathrm{P}$ and $\mathrm{P}, \mathrm{P}) \mathrm{DDD} /(\mathrm{O}, \mathrm{P}$ and $\mathrm{P}, \mathrm{P})$ DDTs can be used to assess whether the DDT input occurred recently or in the past ${ }^{(28)}$. In this study, for investigated ground water, the total DDE/DDT and DDD/DDT ratios ranged between 1.33-0 and 1.35-0, respectively, and for investigated rural water, between 1.92-0 and 1.35-0. Moreover, all sites either ground or rural sites indicated $90 \%$ and $80 \%$ of the water samples, respectively, presented the DDE/DDTs and DDD/DDTs ratios below unity. Since DDE/DDTs and DDD/DDTs ratios in the studied samples are often much lower than unity (Tables 4 and 5), it appears that recent inputs of DDT may still occur in the area.

Aldrin and dieldrin are synthetic organochlorine insecticides. The technical-grade formulations contain no less than $85.5 \%$ of either chemical. Pure aldrin and dieldrin are white powders with mild chemical odor. Aldrin is readily converted to dieldrin in the environment. From the 1950s until 1970 aldrin and dieldrin were widely used as pesticides for crops like corn and cotton. Aldrin and dieldrin were also used as a prophylactic and for treatment of timber against termite infestation until 1987, when all uses were banned. Aldrin and dieldrin are not very water soluble, but readily bind to sediment and are rarely leached in deeper soil layers and groundwater. Dieldrin bioconcentrates and biomagnifies through the terrestrial and aquatic food chains. Prolonged exposure to lower levels has induced headaches, dizziness, irritability, vomiting, and muscle spasms. There is no conclusive evidence that aldrin or dieldrin cause cancer in humans. The USEPA has determined that aldrin and dieldrin are probable human carcinogens. The internal agency for research and 
cancer (IARC) has determined that aldrin and dieldrin are not classifiable as to their carcinogenicity to humans ${ }^{(29)}$. For ground water, Table (2), aldrin not detected in all sites except sites 1 and 8 with concentrations of $0.28 \mu \mathrm{g} / \mathrm{L}$ and $0.36 \mu \mathrm{g} / \mathrm{L}$, respectively, while dieldrin is detected in all sites, except site 8 , with high concentration of $0.56 \mu \mathrm{g} / \mathrm{L}$ at site 2 . On the other hand, aldrin was detected in rural tap water samples, Table (3), at site 2 with concentration of $0.77 \mu \mathrm{g} / \mathrm{L}$. The dieldrin was detected also at all sites, except site 8 , with high concentration of $0.56 \mu \mathrm{g} / \mathrm{L}$ at site 2 .

Hexachlorocyclohexane $(\mathrm{HCH})$, formally known as benzene hexachloride (BHC), is a synthetic chemical that exists in eight chemical forms called isomers. The different isomers are named according to the position of the hydrogen atoms in the structure of the chemical. One of these forms, gamma-HCH (or $\gamma-\mathrm{HCH}$, commonly called lindane), is produced and used as an insecticide on fruit, vegetables, and forest crops, and animals and animal premises. It is also available as a prescription medicine (lotion, cream, or shampoo) to treat and/or control scabies (mites) and head lice in humans. Although technical-grade $\mathrm{HCH}$ is no longer used as an insecticide in the United States, $\alpha-, \beta-, \gamma-$, and $\delta$-HCH have been found in the soil and surface water at hazardous waste sites because they persist in the environment. In humans, breathing toxic amounts of $\gamma-\mathrm{HCH}$ and/or $\alpha-$, $\beta-$, and $\delta-\mathrm{HCH}$ can result in blood disorders, dizziness, headaches, and possible changes in the levels of sex hormones in the blood. These effects have occurred in workers exposed to $\mathrm{HCH}$ vapors during pesticide manufacturing. People who have swallowed large amounts have had seizures; some have died. EPA has also recommended guidelines on how much $\mathrm{HCH}$ can be present in drinking water for specific periods without producing health effects. EPA advises that children should not have more than 1.2 milligrams $\mathrm{HCH}$ per liter of water $(\mathrm{mg} / \mathrm{L})$ for up to 10 days. For lifetime exposure in adults, EPA recommends that there should not be more than $0.0002 \mathrm{mg} / \mathrm{L}$ of $\mathrm{HCH}$ in drinking water. EPA has classified $\mathrm{HCH}$ as a hazardous waste that must meet certain disposal requirements ${ }^{(30)}$. The dominant isomers from both types of waters were $\beta$ - and $\gamma-\mathrm{HCH}$ and are consistent with $\beta$-HCHs environmental degradation difficulty and the large use of $\gamma$ $\mathrm{HCH}$ (lindane). Moreover, losses by volatilization are higher for the $\gamma$ 
isomer. The $\alpha-\mathrm{HCH} / \gamma-\mathrm{HCH}$ ratio can be used to identify the source of $\mathrm{HCHs}$ in water ${ }^{(31)}$. An $\alpha-\mathrm{HCH} / \gamma-\mathrm{HCH}$ ratio in areas where lindane has been used due to the photochemical transformation of $\gamma-\mathrm{HCH}$ into $\alpha-\mathrm{HCH}^{(32 ; 33)}$. In our study, the $\alpha-\mathrm{HCH} / \gamma-\mathrm{HCH}$ ratio in ground and rural tap water ranged between 2.4 and 0 , and 0 respectively. The results showed that for ground water in $80 \%$ of all samples, the $\alpha$ $\mathrm{HCH} / \gamma-\mathrm{HCH}$ ratio was below 1 , and for tap water in $100 \%$ of all samples, indicating lindane $[\gamma-\mathrm{HCH}]$ as the $\mathrm{HCH}$ source. The presence of $\alpha$-and $\gamma-\mathrm{HCH}$ reveals the recent use of technical $\mathrm{HCH} 55-80 \% \alpha$ $\mathrm{HCH}$ and $8-15 \% \gamma-\mathrm{HCH}$, plus other compounds) and lindane (more than $99 \% \gamma-\mathrm{HCH}$ ) in the Ausiem area. The data obtained may be explained by the use of technical $\mathrm{HCH}$ mixtures in the past, and/or due to photochemical transformation of $\gamma-\mathrm{HCH}$ into $\alpha-\mathrm{HCH}$ in the atmosphere, with subsequent deposition in the surface water (Table 5). The results revealed that the $\mathrm{HCHs}$ concentrations were lower than DDTs'. This may be due to their differences in physicochemical and biological properties, having HCHs a higher water solubility, vapor pressure, biodegradability, lower lipophilicity and particle affinity as compared to DDTs properties ${ }^{(34)}$.

Table (4): Ratio between isomers of $\mathrm{HCH}$ and between isomers of DDT for ground water

\begin{tabular}{|c|c|c|c|c|c|c|c|c|c|c|}
\hline & \multicolumn{10}{|c|}{ Sites } \\
\hline Ratio & 1 & 2 & 3 & 4 & 5 & 6 & 7 & 8 & 9 & 10 \\
\hline$\alpha \mathrm{HCH} / \gamma \mathrm{HCH}$ & 1.16 & 0 & 0 & 0 & 0 & 0 & 0 & 2.4 & 0 & 0 \\
\hline $\mathrm{DDE} / \mathrm{DDT}^{\mathrm{a}}$ & 0.39 & 0.47 & 1.33 & 0 & 0.12 & 0 & 0.08 & 0.27 & 0 & 0.17 \\
\hline $\mathrm{DDD} / \mathrm{DDT}^{\mathrm{a}}$ & 0.71 & 0.13 & 1.35 & 0 & 0 & 0 & 0.43 & 0 & 0.04 & 0 \\
\hline
\end{tabular}

a:O,P and P,P

Table (5): Ratio between isomers of $\mathrm{HCH}$ and between isomers of DDT for Rural tap water

\begin{tabular}{|c|c|c|c|c|c|c|c|c|c|c|}
\hline & \multicolumn{10}{|c|}{ Sites } \\
\hline Ratio & 1 & 2 & 3 & 4 & 5 & 6 & 7 & 8 & 9 & 10 \\
\hline$\alpha \mathrm{HCH} / \gamma \mathrm{HCH}$ & 0 & 0 & 0 & 0 & 0 & 0 & 0 & 0 & 0 & 0 \\
\hline $\mathrm{DDE} / \mathrm{DDT}^{\mathrm{a}}$ & 0.24 & 0.14 & 0 & 1.92 & 0 & 0 & 0.12 & 0.08 & 0.13 & 1.53 \\
\hline $\mathrm{DDD} / \mathrm{DDT}^{\mathrm{a}}$ & 0.71 & 0.13 & 1.35 & 0 & 0 & 0 & 0.43 & 0 & 0.04 & 0.06 \\
\hline $\mathrm{a}: \mathrm{O}, \mathrm{P}$ and P,P
\end{tabular}

Heptachlor is converted to heptachlor epoxide in the environment. The heptachlor epoxide is degraded more slowly and is thus more persistent. Heptachlor partitions somewhat rapidly to the 
atmosphere from surface water and that volatilization is significant. In contrast, heptachlor epoxide partitions slowly to the atmosphere from surface water. Heptachlor in water has an estimated half-life of 3.5 days. Heptachlor epoxide has a half-life in water of at least 4 years. Heptachlor and heptachlor epoxide adsorb strongly to sediments. Temperature and humidity affect the persistence of heptachlor and heptachlor epoxide in soil, as can the amount of organic matter present. Heptachlor and heptachlor epoxide are also taken up by plants and both may bioconcentrate in aquatic and terrestrial food chains. The International Agency for Research on Cancer (IARC) classifies heptachlor as a possible human carcinogen. The EPA classifies heptachlor and heptachlor epoxide as probable human carcinogens. Minimal Risk Levels (MRLs) of $0.0006 \mathrm{mg} / \mathrm{kg} /$ day has been derived for acute-duration oral exposure ( $<14$ day) to heptachlor. An MRL of $0.0001 \mathrm{mg} / \mathrm{kg} /$ day has been derived for intermediate-duration oral exposure (15-364 days) to heptachlor ${ }^{(35)}$. The present study revealed that for ground water heptachlor was detected only at sites 2, 8 and 9 with concentrations of $1.75,0.32$ and $0.1 \mu \mathrm{g} / \mathrm{L}$, respectively. On the other hand, all sites indicted the contamination by heptachlor epoxide with high concentration of $0.65 \mu \mathrm{g} / \mathrm{L}$ at site 10 and low concentration of $0.1 \mu \mathrm{g} / \mathrm{L}$ at sites 1,3 and 8 , respectively. Furthermore, the data listed in Table (3) indicating the contamination of rural tap water samples by heptachlor more than heptachlor epoxide, where the study revealed that the high concentration was $3.19 \mu \mathrm{g} / \mathrm{L}$ and showed at site 4. Although heptachlor is converted rapidly in the environment to heptachlor epoxide as mentioned earlier the obtained data was unexpected.

\subsection{Existence of organophosphorus pesticides}

Organophosphates (OPs) are a class of pesticides, several of which are highly toxic. Until the $21^{\text {st }}$ century, they were among the most widely used pesticides available. They are used in agriculture, homes, gardens and veterinary practices. All share a common mechanism of cholinesterase inhibition and can cause similar symptoms, although there are some differences within the class. Since they share this mechanism, exposure to organophosphates by multiple routes may lead to serious additive toxicity. Furthermore, all can potentially cause acute and subacute toxicity ${ }^{(36)}$. Symptoms of acute organophosphate 
poisoning develop during or after exposure, within minutes to hours, depending on method of exposure. Exposure by inhalation results in the fastest appearance of toxic symptoms, followed by the oral route and finally the dermal route. All signs and symptoms are cholinergic in nature and affect muscarinic, nicotinic and central nervous system receptors ${ }^{(37)}$. Some of the most commonly reported early symptoms include headache, nausea, dizziness and hypersecretion, the latter of which is manifested by sweating, salivation, lacrimation and rhinorrhea. Muscle twitching, weakness, tremor, incoordination, vomiting, abdominal cramps and diarrhea all signal worsening of the poisoned state ${ }^{(38)}$. Table (2) showed that the total OP for ground water was detected at site 1 with concentration of $4.35 \mu \mathrm{g} / \mathrm{L}$ followed by $2.44 \mu \mathrm{g} / \mathrm{L}$ at site 2 , while sites 5 and 6 indicating no contamination by OP. On the other hand, for investigated rural water the data listed in Table (3) indicted that the rural tap water was moderately more polluted than ground water by OP pesticides. The sites 8 and 7 were the highest contaminated with concentration of 5.57 and $2.56 \mu \mathrm{g} / \mathrm{L}$, respectively .

\section{Conclusion}

Some of investigated organochlorine and organophosphorus pesticides have been found to have a widespread distribution within ground and rural tap water. The high concentrations of OC pesticides, in investigated ground and rural water can be attributed to its high resistance and accumulation in the environment. The DDT pattern, as well as in the ratios between metabolites and the parent compound, may reflect recent DDT inputs, despite its ban. The existence of HCHs in ground water also indicates recent usage and/or more accumulation of it in Ausiem area. The presence of OP also indicates the regular and recent usage of it. 


\section{References}

1- Peter O, Lin KC, Karen P, Joe A. (2002). Persistent Organic Pollutants (POPs) and Human Health. Washington: World Federation of Public Health Association Publications; p. 1-35.

2- Dogheim, S. M., El-Zarka, M., Gad All, S., El-Said, S., Salama, E.,Ayoub, M., \& Fahmy, S. (1996). Monitoring of pesticide residues in human milk, soil, water and food samples collected from Kafr El-Zayat Governorate. Journal of the Association of Official Analytical Chemists Journal (JAOAC), 79(1), 111-116.

3- Abdallah, A. M., \& Ali, H. A. (1994). Residue levels of chlorinated hydrocarbons compound in fish from El-Max Bay and Maruit Lake, Alexandria, Egypt. Toxicological and Environmental Chemistry, 42, 107-114.

4- El-Kabbany, S., Rashed, M. M., \& Zayed, M. A. (2000). Monitoring of the pesticide levels in some water supplies and agriculture land, in El-Haram, Giza (A.R.E.). J Hazardous Materials, 72(1), 11-21.

5- Mansour, S. A., Mahram, M. R., \& Sidky, M. S. (2001). Ecotoxicological studies. Monitoring of pesticide residues in the major components Lake Qarun, Egypt. Journal of Egyptian Academic Society for Environmental Development, 2, 83-116.

6- Yamashita, N., Urushigawaa, Y., Masunaga, S., Walash, M. I., \& Miyazaki, A. (2000). Organochlorine pesticides in water, sediment and fish from the Nile River and Manzala Lake in Egypt. International Journal of Environmental Analytical Chemistry, 77(4), 289-303.

7- Barakat, A. O., Kim, M., Qian, Y., \& Wade, T. L., (2002). Organochlorine pesticides and $\mathrm{PCB}$ residues in sediments of Alexandria Harbour, Egypt. Baseline/Marine Pollution Bulletin, 44, 1421-1434.

8- Abbassy, M. S., Ibrahim, H. Z., \& Abdel-Kader, H. M. (2003). Persistent organochlorine pollutants in the aquatic ecosystem of Lake Manzala, Egypt. Bulletin of Environmental Contamination and Toxicology, 70(6), 1158-1164.

9- El-Kady, A. A., Abdel-Wahhab, M. A., Henkelmann, B., Belal, M. H., Morsi, M. K. S., Galal, S. M., \& Schramm, K. W. (2007). Polychlorinated biphenyl, polychlorinated dibenzop-dioxin and polychlorinated dibenzofuran residues in sediments and fish of the River Nile in the Cairo region. Chemosphere, 68, 16601668.

10- Malhat, F. M. M. (2010). Organochlorines and organophosphours pesticides, petroleum hydrocarbons, polychlorinated biphenyls and trace metal monitoring of Nile River in Egypt. Ph.D. Thesis. Chemistry Department, Faculty of Science, Menofiya University.

11- Dahshan., M.; Megahed, A; Abdel-All, A. (2016). Monitoring of pesticides water pollution-The Egyptian River Nile. Journal of Environmental Health Science \& Engineering 14:15.

12- Crentsil , B., Jacob A., Daniel A., Juliana B., Stephen B. (2012). Contamination levels of selected organochlorine and organophosphorus pesticides in Ghanaian fruits and vegetables, J. Food Agric. 24 (4): 293-301. 
13- Chambers, H. W., J. S. Boon, R. L. Carr and J. E.Chanbers. (2001). Chemistry of organophosphorus insecticides. In: I. K. Robert, (Ed), pp.913-917. Handbook of Pesticide Toxicology (2nd Ed.), Academic Press, California, USA.

14- Westbom, R., Hussen, A., Megersa, N., Retta, N., Mathiasson, L., \& Bjrklund, E. (2008). Assessment of organochlorine pesticide pollution in Upper Awash Ethiopian state farm soils using selective pressurised liquid extraction. Chemosphere, 72, 1181-1187.

15- Jorgenson, J. L. (2001). Aldrin and dieldrin: a review of research on their production, environmental deposition and fate, bioaccumulation, toxicology and epidemiology in the United States, Environ. Health Perspect. 109:113-139.

16- Gilliom R.J. (2007). Pesticides in US streams and groundwater. Environ Sci. Technol., 41:3408-3414.

17- Howard P.H. (1991). Hand book of environmental fate and exposure data for organic chemicals. Lewis, Chelsea.

18- Eichenberger J.W., Litchenberg J.J. (1971). Persistence of pesticides in river water. Environ. Sci. Technol., 5:541-544.

19- Tsuda T., Nakamura T., Inoue A., Tanaka K., (2009). Pesticides in water, fish and shellfish from Littoral area of lake Biwa. Bull Environ Contam Toxicol 82:716721.

20- Hela D.G., Lambropoulou D.A., Konstantinou I.K., Albains T.A,. (2005). Environmental monitoring and ecological risk assessment for pesticide contamination and effects in Lake Pamvotis, Northwestern Greece. Environ Toxicol Chem 24:1548-1556.

21- Shayegh M., Shahtaheri S.J., Selsel M., (2001). Phosphorous insecticides residues in Mazandaran river waters. Iran. Iranian J Public Health 30:115-118.

22- USEPA, 1980. In: Watts, R.R. (Ed), analysis of pesticide residues in human and environmental samples- Compilation of methods selected for use in pesticide monitoring programs. EPA-600/80-038.

23- Rand G.M., Wells P.G., Mclarty L.S., (1995). In: Rand GM, editor. Introduction to aquatic toxicology. Washington7 Taylor and Francis; p. 3-66.

24- [24]- Belfroid A.C., Van Drumen M., Beck M.A., Vangestal C.A.M., Van Hattun B. (1998). Relative risks of transformation products of pesticides for aquatic ecosystems. Sci Total Environ;222:167-83.

25- IPCS (1989). DDT and its derivatives - environmental aspects. Geneva, World Health Organization, International Programme on Chemical Safety (Environmental Health Criteria 83).

26- [26]- Meybeck M, Chapman D, Helmer R, eds. (1989). Global freshwater quality: WHO/UNEP Global Environment Monitoring System. Oxford, Alden Press.

27- World Health Organization (2004). DDT and its Derivatives in Drinking-water, 115.

28- Loganathan, B.G., Kannan, K., (1994). Global organochlorine contamination trends: an overview. Ambio 23, 187-191. 
29- Agency for Toxic Substances and Disease Registry (ATSDR). (2002). Toxicological Profile for Aldrin/Dieldrin (Update). Atlanta, GA: U.S. Department of Health and Human Services, Public Health Service.

30- Agency for Toxic Substances and Disease Registry (ATSDR). (2005). Toxicological profile for Hexachlorocyclohexane. Atlanta, GA: U.S. Department of Health and Human Services, Public Health Service.

31- Zhang, Z.L., Hong, H.S., Zhou, J.L., Yu, G., (2003). Fate and assessment of persistent organic pollutants in water and sediments from Minjiang River Estuary, Southeast China. Chemosphere 52, 1423-1430.

32- McConell, L. L., Cotham, W. E. \& Bidleman, T. F. (1993). Gas exchange of hexachlorocyclohexane in the Great Lakes. Environment Science \& Technology 27, 1304-1311.

33- Maldonado, C., Bayona, J.M., (2002). Organochlorine compounds in the Northwestern Black Sea water: distribution and water column process Estuar. Coast. Shelf Sci. 54, 527-5.

34- Kannan, N., Yamashita, N., Petrick, G. \& Duinker, I. C. (1998). Polychlorinated biphenyls and nonylphenols in the Sea of Japan. Environment Science \& Technology 32, 1747-1753.

35- Agency for Toxic Substances and Disease Registry (ATSDR). (2007). Toxicological Profile for Heptachlor and Heptachlor Epoxide. Atlanta, GA: U.S. Department of Health and Human Services, Public Health Service.

36- EPA, (2013). Recognition and management of pesticide poisoning: 6Th Ed. Chapter 5 organophosphates.

37- Taylor P. (1985). Anticholinesterase agents. In: Gilman AG, Goodman LS, eds. The pharmacological basis of therapeutics. New York: Macmillan Publishing Co., Inc; $110-128$.

38- Okudera H. Clinical features on nerve gas terrorism in Matsumoto. J Clin Neurosci. Jan 2002;9(1):17-21. 


\section{توزيع وتنوع بعض هبيدات الآفات فى المياه الجوفية وهياه الصنبور بمدينة أوسيم بممافظة البيزة}

هبدى همدبولى

أجريت هذه الدراسة لمعرفة توزيع وتتوع بعض مبيدات الآفات الكلورينية العضوية(OC) والفوسفورية

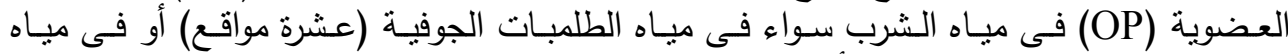

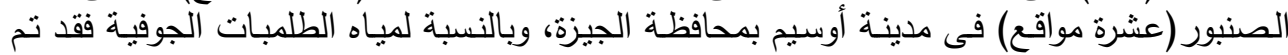

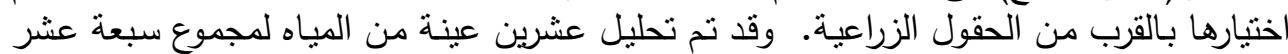

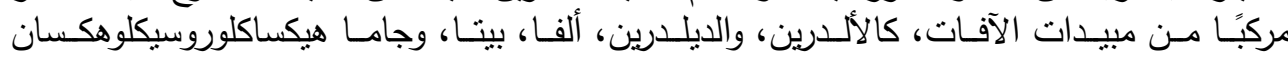

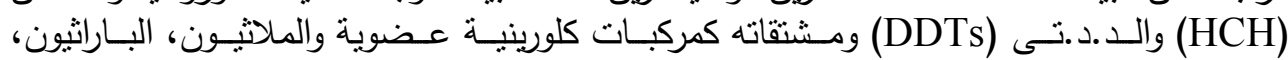
الدايميثوات والتولكلوفوس ميثيل كمبيدات عضوية فوسفورية.

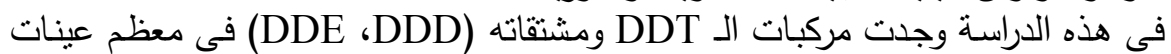

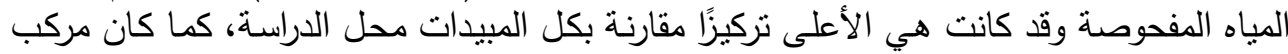

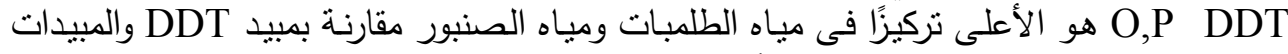

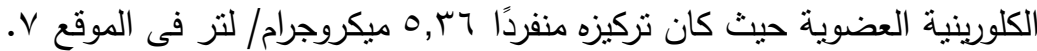

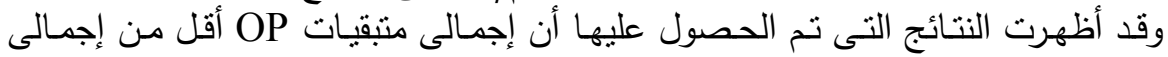

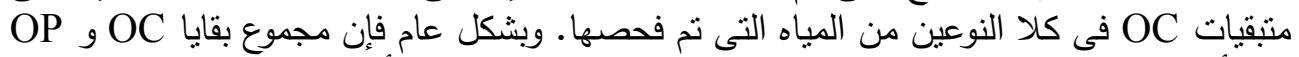

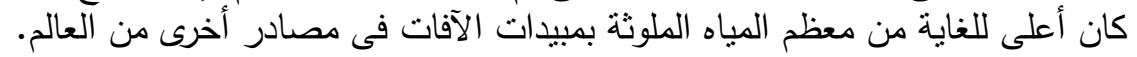

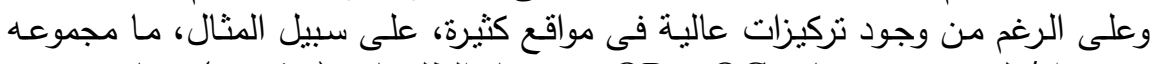

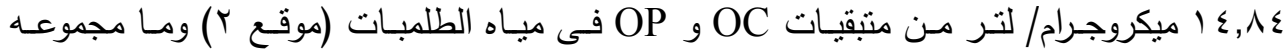

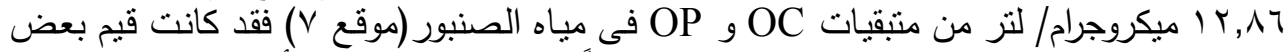

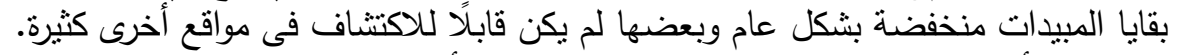

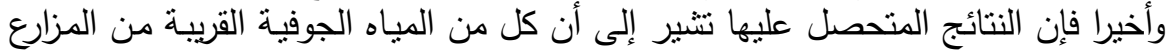

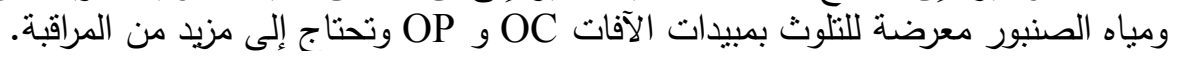

